\title{
Challenges and Induction Needs of Novice English as a Foreign Language Teachers in Saudi Arabia
}

Rufaida Alhamad*

Curriculum and Instruction Department, College of Education, King Saud University, Saudi Arabia

Corresponding author: Rufaida Alhamad, E-mail: Rufad.h@gmail.com

\section{ARTICLE INFO}

Article history

Received: July 01, 2017

Accepted: January 29, 2018

Published: January 31, 2018

Volume: 6 Issue: 1

Conflicts of interest: None

Funding: None

\begin{abstract}
The first year of teaching poses massive challenges that lead to attrition among novice teachers. School communities often fail to provide adequate support to novice teachers to help them adapt to their new professional environments. In Saudi Arabia, attrition among novice teachers is a significant problem that hinders the development of the educational system. This study was conducted to examine the challenges that Saudi Arabian EFL novice teachers face as they transit into their first teaching jobs, and to determine whether these teachers have adequate support or would benefit from a formal induction process. Two kinds of data collection methods were used in this study, namely quantitative and qualitative. In this mixed methods study, 150 novice teachers were surveyed and 5 teachers were selected for semi-structured interviews. The quantitative analysis of the data was accomplished using descriptive and inferential statistics to answer the research questions. The qualitative analysis of the data was accomplished by interpreting the responses provided to the interview questions. The findings indicated that the challenges surrounding novice teachers hinder them in their development as new teachers. The most conspicuous challenges reported by the study participants were dealing with low English proficiency students and managing the negative attitudes of students toward learning English. This report also determined additional perceptible challenges: adoption of various teaching methods and the establishment of a student-centered approach, student behavior management, course planning, dealing with individual differences, and communication with parents. This study showed that these teachers had left their pre-service training with a very limited knowledge and skills for dealing with the reality of teaching. Mentoring and observing veteran teachers were identified by novice teachers as the two most beneficial strategies for implementing a teacher induction program that could mitigate the challenges they face in their first few years.
\end{abstract}

Key words: EFL Novice Teacher, Teacher's Challenges, Induction Needs

\section{INTRODUCTION}

Teachers are the most effective factors in English language education. They play crucial roles in students' learning and achievement (Darling-Hammond, 2003). Shafie and Nayan (2010) discussed the key roles teachers are expected to play in educational settings: knowledge transmitter, role model, facilitator, student assessor, curriculum assessor, and course planner. Due to the powerful roles teachers play, they are supposed to have adequate preparations and qualifications. Accordingly, decision-makers worldwide have begun paying attention to professional-development strategies that increase teacher qualification and education.

The Saudi Ministry of Education is no exception. Its leaders have paid great attention to preparing English as a foreign language (EFL) teachers. Saudi Arabian English teachers are trained in programs provided by English language departments at various Saudi University Colleges of Arts and Colleges of Education. Later, teachers attend in-ser- vice training programs to learn modern teaching methods (Al-Hazmi, 2003). However, teachers' college educations and in-service experiences (often limited by time and scale) do not address the complex demands of their work (Caspersen \& Raaen, 2014).

This gap between pre-service teacher preparation and in-service teacher development and everyday classroom realities drives novice teacher attrition (Brighton, 1999). Novice teachers often find themselves lost; from their very first day of employment, supervisors expect them to do the work of experienced teachers. They have to deal with many different challenges simultaneously: stimulating students' learning, managing classroom discipline, integrating students with special needs into classes, using technology, and individualizing student programs. New teachers need help and support to put their college educations into practice and adapt to their new professional environments. They also need assistance in increasing their job success and self-confidence to bring 
out the best in their students. Thus, it is essential to provide a supportive environment for novice teachers during their transition from pre-service to in-service.

A supportive environment is valuable for novice teachers (Harrison, Lawson\& Wortley, 2005). Elliott and Pynchon (2005) found that supportive programs increase teachers' satisfaction, reduce their isolation, and enhance their professional growth. For this reason, novice teaches must be supported via induction and mentoring programs)Bickmore \& Bickmore, 2010; Ingersoll \& Strong, 2011). Barnett et al. (2002) define induction programs as systematic processes of assistance for beginning teachers undertaken by specifically-assigned professionals. Researchers confirm that beginning teachers involved in induction programs showed significant improvements in effectiveness, job satisfaction, and positive acclimation to school cultures (Heller, 2004).

Despite the positive impacts of the induction program, there is little, if any, systematic professional support available to new teachers in Saudi Arabia (Alharbi, 2011). Many beginning Saudi teachers learn by trial-and-error, so this has a negative impact on teachers and students' achievement. Alsaghyer (2014) demonstrated the inadequate preparation of English teachers. These teachers graduate from colleges without proper EFL training. Giraldo (2014) found professional development programs are not effective unless based on teachers' philosophies, needs, experience, practice, and reflections. For this reason, many research studies have been conducted to investigate the experience and challenges of novice teachers; however, based on the researcher's knowledge, only few related studies have been conducted in Saudi Arabia. Thus, the researcher is motivated to investigate the challenges Saudi Arabian EFL novice teachers face during their transition into their first teaching jobs and ascertain the induction strategies they require.

\section{Objectives}

The study's purpose was to investigate the challenges that EFL novice teachers in Saudi Arabia face during their transition into their first teaching jobs and to determine whether these beginning teachers should go through an induction process.

\section{Research Questions}

The following research questions were posed to address the aforesaid objective:

1) What are the major challenges that novice Saudi EFL teachers face?

2) What kind of support do new teachers receive in Saudi Arabian schools?

3) What types of strategies are effective to implement a teacher induction program as perceived by EFL novice teachers?

\section{LITERATURE REVIEW}

\section{Challenges Faced by Novice Teachers}

The initial period of a teacher's professional life is a "shock phase" in which many beginning teachers experience reality shock. They often come to realize that their visions of teaching before joining the profession were quite opposite from the realities they encounter (Huberman, 1989). Hebert and Worthy (2001) reported similar results. Based on a case study of first-year teachers over the course of an academic year, Hebert and Worthy (2001) declared that most beginning teachers experience reality shocks, as their idealistic expectations of teaching do not match up with reality. The complex realities novice teachers face have been addressed extensively by plenty of studies over the past thirty years. Veenman (1984) analyzed 100 international empirical studies to identify the most serious problems for beginning teachers; he identified the problems of organization of class work, motivating pupils, dealing with individual differences, classroom discipline, assessing pupils' work, relations with parents, insufficient materials and supplies, and dealing with individual pupils' problems. Meister and Melnick (2003) endeavored to better understand the concerns of beginning teachers by documenting the experiences of 273 first and second-year teachers across the United States. In their examination of novices' perceptions (as they transitioned from pre-service to in-service training), three major concerns stood out: managing the behaviors and diverse needs of students, time constraints and workloads, and conflicts with parents and other adults.

While extensive literature has focused on beginning teachers' problems, challenges, and failures, some reports in the literature claim that the first year of teaching does not necessarily have to be difficult. These researchers highlight teachers who do more than survive the first year - they actually succeed. For example, Solmon et al. (1993) asserted (in a multi-case study) that participants were able to adapt to situations, achieve senses of accomplishment, and gain self-confidence and experience - despite experiencing typical first-year challenges. Likewise, Hebert, and Worthy (2001) reported on a case study of successful firstyear teaching. As reported in the study, the factors that led to success included pre-service teacher preparation, school contexts, and the participant's personality and actions. Hebert and Worthy (2001) found that experiential learning in schools during undergraduate teacher preparation (in which student teachers faced early failures) resulted in enhanced personal meanings of future teacher preparations.

Although the first year of teaching has been intensively addressed in general education, there are not enough studies investigating the experiences of language teachers in their first years of teaching, as seen in the Teaching of English to Speakers of Other Languages (TESOL) education literature (Farrell, 2008). One study that took the TESOL context into account was by Fareh (2010), who surveyed hundreds of English language teachers in Arab countries like Jordan, the West Bank, Syria, Sudan, Yemen, Morocco, Saudi Arabia, and the United Arab Emirates. Fareh explored the challenges of teaching English in Arab countries. This study's results show the adoption of the various teaching methods was challenging for EFL teachers; most of them used only the Grammar Translation method. Meeting individual needs, motivating students to learn, encouraging students to be involved in the learning process, and a lack of teaching sources 
were examples of the challenges EFL teachers faced (Farah, 2010). Farrell (2003) also discussed challenges and personal influences in a case study of a first-year English teacher in Singapore. The findings indicated that the participant struggled with the setting, correcting examination papers, and his relationships with his low-English-proficiency students.

\section{EFL Novice Teachers in Saudi Arabia}

Teacher attrition in the first years is a universal problem. Novice teachers in Saudi Arabia are no exception. A national study by Alromaih (1995) on "Professional and personal growth needs of beginning high school teachers in Saudi Arabia and the need for induction programs as viewed by administrators" provided a general picture of the challenges novice teachers from various fields faced during their first years. Alromaih (1995) surveyed 137 Saudi principals to examine their perceptions of the areas in which novice teachers need induction and support. The results indicated that most Saudi novice teachers should go through an induction program since they significantly are deficient in essential teaching competencies (knowledge of their subject matter).

Alromaih (1995) also identified (through the principals' perceptions) other challenges in which novice teachers rated them as very important to not important on a three-point Likert scale. The areas ranked very important were commitment to their professions, punctuality, classroom management, planning and sequencing of instructions, addressing students' individual differences, creating rapport with their colleagues, followed by maintaining positive attitudes toward students, motivating students, encouraging students' self-esteem, preparing and using a variety of teaching materials. The challenges ranked important were caring for physical facilities and equipment, using varied instructional strategies, developing students' thinking skills, assessing student progress, paying attention to students' health and safety, knowing the current research in the education field, developing communication skills, and handling routine procedures. This study results provide a general understanding of the new teachers experience and their needs for induction program. However, the study used only a questionnaire to collect data which unlikely to provide in depth detail. The study also didn't investigate teachers' perceptions.

In the TESOL field, studies on EFL teachers' preparation and professionalism provided only a general picture of the challenges EFL teachers may face. Foreign language preparation programs, as Alseghayer (2014) explained, require a four-year bachelor's degree in linguistics, teaching methodologies, English literature, and education courses. English teaching methods represented only $10 \%$ of the total courses; this included a teaching practicum course offered in the last semester of these English academic programs (Alseghayer, 2014). Alfahadi (2014) emphasized no previous training or experience was required of teachers besides this bachelor's degree - despite the shortage of teaching methods and practicum. In a recent study, Al-Seghayer (2014) highlighted improperly trained teachers, inadequate teaching methodologies, and teacher-centered (rather than learner-centered) activities as challenges that influenced the efficiency of Saudi
Arabian EFL programs. Alkubaidi (2014) explained that, in the Saudi academic culture, teachers dominate the learning process. Students rely on teachers as their main source of knowledge and take a passive role in the learning process. Alfahadi (2014) agreed that EFL teachers in the Saudi Arabian context lacked sufficient training to deal with various new teaching techniques and activities. Al-Seghayer (2014) detected constraints that affected Saudi Arabian English teaching in several areas, including students' beliefs, aspects of curricula, pedagogy, and administrative processes. The most common constraint reported by Al-Seghayer (2014) was the negative beliefs and attitudes students bring to EFL classrooms, which keeps them unenthusiastic and unmotivated to learn English. The aforementioned studies attempt to identify the challenges that teachers encounter in teaching English in Saudi Arabia, however, they did not focus on novice teachers' perceptions and the supports that they need to mitigate the challenges.

\section{Inductions Programs}

A high rate of novice teacher burnout, attrition, and challenging experiences persisted across the literature. It is imperative to support novice teachers as they transit from student roles to teacher roles. Researchers revealed many potential benefits of induction and mentoring programs over novice teachers. Villar (2004) found that teachers in induction programs show rapid improvement in their teaching skills and capacities; this minimized the time they needed to reach the same ability levels as experienced teachers. Alromaih (1995) determined important induction strategies that are necessary to mitigate the challenges faced by novices as perceived by school principals and their deputies. Orientation and instructional supervision were the top strategies identified as very important for implementing a teacher induction program. The remaining important identified strategies were observation, demonstration, attendance at professional conferences, micro-teaching, followed by practical training, team teaching, group discussion, teacher mentoring, workshops, and collaboration with other educational institutes.

Despite intensive literature on the potentially positive effects of mentoring and induction, some studies reported on limitations and disadvantages of these methods. Beck and Kosnick (2000) concluded that mentoring does not give new teachers sufficient freedom to innovate. Feiman, Nemser, Parker, and Zeichner (1993) reported that some restrictive forms of mentoring can result in the promotion and reproduction of conventional norms and practices. This prevents new teachers from developing and consolidating their latest and most novel knowledge and approaches and challenging the traditionalism inherent in teaching (Clarke \& Jarvis-Selinger, 2005; Sundli, 2007).

The aforementioned literature provides a general picture of the challenges novice teachers in various fields faced during their first years. They also shed light on the effects of induction. However, they did not accurately describe the challenges and needs of ESL novice teachers in their first years of ESL teaching in Saudi Arabia. There is a need to fill this gap in the research. Understanding novice teachers' challenges will 
make it possible to determine the support new teachers need. This will allow administrators, district boards, the Ministry of Education, and all other stakeholders to efficiently support the success of newcomers to the profession and enhance the experiences of teaching and learning English in Saudi Arabia.

\section{METHOD}

\section{Research Approach and Design}

In this study, mixed-methods approach was adopted, in which quantitative and qualitative analyses were used to obtain the individualized perspectives of Saudi novice teachers regarding the challenges of their first years of teaching, the efficacy of existing workplace support mechanisms, and the induction practices that would be most beneficial to them in mitigating the challenges they face. The quantitative analysis was undertaken by use of a survey, while the qualitative analysis was informed by a semi-constructed interview. The use of a mixed approach added value to the study's research findings in a manner that could not be achieved merely through one form of data (Tashakkori \& Teddlie, 1998).

\section{Sample}

The target population of this study included Saudi novice ESL teachers (both male and female) with a maximum of three years of teaching experience at elementary, intermediate, and secondary schools. The survey sample comprised 106 female teachers and 44 male teachers from all different levels of public and private schools. The participants were selected randomly in order to represent the broader target population.

The sample used for the semi-constructed interviews was purposefully selected to include participants from different levels of schools and with varying degrees of teaching experience, in order to capture perspectives from different types of teachers. This interview sample comprised five female ESL teachers. As a result of male/female segregation in the Saudi educational system, a female researcher has very limited access to boys' schools. Therefore, distributing and collecting surveys from male respondents presents a real challenge to a female researcher, and conducting interviews is even harder. This explains the low number of male survey participants compared to females and the absence of interviews with male participants.

\section{Instruments}

Data was collected from novice teachers by means of a survey and semi- structured interviews. For the quantitative portion of the study, a survey instrument was developed based on concerns and needs that were identified in previous studies as being significant to novice teachers. As noted by Bryman (2008), questionnaires provide a researcher with more standardized data and reduce the possible effect of the researcher's presence on answers given by the participants. The survey consisted of closed-ended questions as well as questions based on a Likert scale (Appendix A). The survey comprised four parts. Part one of the survey requested demographic information, including such details as (a) gender, (b) length of service as teacher, and (c) academic qualifica- tions at the time of the respondent's initiation as a teacher. These variables were necessary in order to cross-validate and interpret the findings. Part two of the survey included a question that determined the degree to which each of 14 variables posed a challenge to the novice teacher, as measured by a Likert scale. Part three comprised a question exploring the efficacy of the assistance and guidance that the novice felt was available in his/her workplace. Finally, part four explored the types of induction practices that the respondents felt would mitigate the challenges faced by new teachers.

For the qualitative portion of the study, semi-structured interviews were conducted to seek more in-depth data from the participants. The framework adopted for the semi-structured interview questions was based on the responses received to the survey questions and the analysis of those responses pertaining to the challenges reported by participants, their perception of support found at their workplace, and their induction needs (Appendix B). The interviews also sought information as to whether the participants had given any consideration to leaving the teaching profession as a direct result of their experiences as new teachers.

\section{Data Collection}

For this study, 219 survey copies were randomly distributed to novice teachers by two methods. First, the researcher personally distributed the surveys to teachers in visits to various schools. Second, the researcher sent a link to an electronic copy of the survey via email to a number of Saudi novice teachers. An online survey was chosen for the advantages of reaching participants who would otherwise be difficult to connect with during the time frame available to the current study, such as those living in a different region of the country. Moreover, because of the challenges presented by gender segregation, use of an online survey was necessary to facilitate access to male teachers. A total of 150 completed surveys were sent back.

The interview sample was selected from among those who completed the surveys. The researcher specifically asked some of the survey respondents if they would consent to being interviewed, if chosen. From among those who agreed, the researcher selected five female participants teaching at different school levels and with varying amounts of teaching experience. To avoid causing stress to participants, interviews were conducted based on the participants' preferences either face-to-face or by telephone.

\section{Data Analysis}

For the quantitative study, SPSS statistical analysis software (Version 22) was used to analyze the survey data on two levels, namely descriptive and inferential. At the descriptive level, the frequencies, percentages and mean scores of the participants' responses were determined to identify the degree of challenge presented by each of the 14 challenges that were identified in other published studies as being significant. The frequencies, percentages, and mean scores of the participants' responses were also calculated to determine the extent to which new teachers found the assistance provided by supervisors, principals, colleagues, and trainers helpful in mitigating such chal- 
lenges, on a scale of "very greatly" to "very poorly." Furthermore, a similar analysis method was used to determine the induction practices that would help to mitigate the challenges that new teachers face, as perceived by them. For the qualitative study, all five interviews were transcribed into a Word document. Using the research questions as a framework, the transcribed data were coded, categorized, and interpreted based on the connections, common aspects, and linkages among them.

\section{Validity of the Instrument}

The validity of an instrument is defined as the extent to which the instrument actually measures what it is assumed to measure (Gay, 1987). The validity of this study was established through two methods. First, the instrument was sent to three faculty members with PhDs in the TESOL field for review, revision, and modification. Based on their suggestions, slight changes were made to the content and language. One question was deleted because it was beyond the scope of the study. Second, the validity of this study was also established through a field test. The field test included five novice teachers who were chosen at random. The participants reviewed the instrument with a focus on clarity of the language and the directions. They indicated that the directions were clear and provided some suggestions regarding the clarity of language. Based on the field test results, the language of items 2 and 9 in section 2 were modified for more clarification. The participants in the field test were excluded from this study's sample.

\section{Reliability of the Instrument}

Gay (1987) defines reliability as the degree to which an instrument produces stable and consistent results. A correlation coefficient can be used to assess the degree of reliability (Gay, 1987). In this study, the survey instrument's reliability was assessed by computing the Cronbach's alpha correlation coefficient, which measures the internal consistency of each scale involved in the instrument. Cronbach's alpha reliability coefficient usually ranges between 0 and 1 ; the nearer it is to 1.0, the higher the internal consistency of the items in the scale (Cronbach, 1951). For the challenges faced by novice teachers section, the items involved in this scale were found to be statistically significant, with an alpha value of 0.807 , representing a good degree of reliability.

For the efficacy of the assistance found by novice teachers section, the items involved in this scale were found to be questionable, with an alpha value of 0.608 . However, Streiner (2003) noted that a low Cronbach's alpha value can be caused by a low number of questions or items. This is because the alpha is also influenced by the length of the test; if the test length is too short, the value of the alpha is decreased. As shown in Table 9, this scale only included four items.

\section{RESULTS}

\section{Demographic Information about the Participants}

Demographic information includes details such as (a) gender, (b) length of service as teacher, and (c) academic qualifi- cations at the time of the respondent's initiation as a teacher.

As shown in Table 1, the majority $(95.3 \%(\mathrm{~N}=143))$ of the participants started teaching with a bachelor's degree for both male and female. It is interesting to note that further education is not essential to become an ESL teacher in a school, as only $2.7 \%(\mathrm{~N}=4)$ of the participants hold a master's degree and only $0.7 \%(\mathrm{~N}=1)$ have a PhD. Similarly, to begin teaching English in schools with an alternative to an associate's degree or bachelor's degree is uncommon, as the participants who started teaching with diplomas represent only $1.3 \%(\mathrm{~N}=2)$ of the participants.

The table also displays the frequency and percentage of the participants' years of experience. The highest percentage of the participants are those with three years of experience; they represent $54.7 \%(\mathrm{~N}=82)$ of the total. Participants with two years' experience represent $25.3 \%(\mathrm{~N}=38)$, while $14(9.3 \%)$ have one year of experience. The sample also includes participants $(10.7 \%(\mathrm{~N}=16))$ with less than one year of experience.

\section{Survey Results}

To analyze the quantitative data and to provide descriptive statistics, SPSS (Statistical Package for the Social Sciences, version 24) was used. The following format is used to provide answers to each research question: (a) restatement of the research question, (b) tabulation of the findings based on the means, frequencies, and percentages of the participants' responses to the related categories of the survey, and (c) the interpretation of the findings based on the overall perceptions of the related respondents

\section{Research Question 1: What are the major challenges that novice Saudi Arabian EFL teachers face?}

A number of challenges for novice teachers were investigated based on 14 challenges identified in the literature as being significant in other studies. Based on their experience as new teachers, respondents were asked to select, from a scale of "very challenging" to "not challenging", the degree of challenge for each posed item. Table 2 demonstrates the fourteen challenges in order of the most challenging to the least challenging, as reported by the participants. As a result, positive participant responses are indicated by a greater mean.

As shown in Table 2, the most noticeable challenge was "Dealing with Low English Proficiency Students." with a mean of 3.75 while "Communication with Colleagues" found to be the least noticeable challenge with a mean of 2.19. However, each challenge was examined separately to determine the degree of challenge each of 14 variables posed.

As shown in Table 3, 59.3\% of the teachers rated "Dealing with Low English Proficiency Students" "very challenging" to "challenging" while $26 \%$ rated it "moderately." Only $14.7 \%$ of the participants rated it "not challenging" or "slightly challenging". So "Dealing with Low English Proficiency Students" can be described as the top challenging factor.

"Managing the Negative Attitude of Students toward Learning English" was found to be the second biggest challenge with a mean of 3.69. Table 4 reveals that over half of the participants $(57.7 \%)$ found it very challenging to chal- 
Table 1. Frequency of the Participants' teaching experience comparing with Gender and Degree

\begin{tabular}{|c|c|c|c|c|c|c|}
\hline Experience/Degree & Bachelor & Diploma & PhD & Master & Grand Total & Percent \\
\hline Less than a year & 14 & 2 & & & 16 & 10.7 \\
\hline Female & 12 & 2 & & & 14 & 9.3 \\
\hline Male & 2 & & & & 2 & 1.3 \\
\hline 3 Years & 78 & & 1 & 3 & 82 & 54.7 \\
\hline Female & 60 & & & 1 & 61 & 40.7 \\
\hline Male & 18 & & 1 & 2 & 21 & 14.0 \\
\hline 1 Year & 14 & & & & 14 & 9.3 \\
\hline Female & 7 & & & & 7 & 4.7 \\
\hline Male & 7 & & & & 7 & 4.7 \\
\hline 2 Years & 37 & & & 1 & 38 & 25.3 \\
\hline Female & 23 & & & 1 & 24 & 16.0 \\
\hline Male & 14 & & & & 14 & 9.3 \\
\hline Grand total & 143 & 2 & 1 & 4 & 150 & \\
\hline Percent & 95.3 & 1.3 & 0.7 & 2.7 & 95.3 & \\
\hline
\end{tabular}

lenging and $33.0 \%$ rated it "moderately." Only $12 \%$ of the teachers claimed the opposite.

"Adoption of Various Teaching Methods" and "Establishment of Student-Centered Approach" had an identical mean score of 3.27 . As shown in Table 5, 45.3\% of the participants found "Adoption of Various Teaching Methods" to be challenging, $33.3 \%$ labeled it "moderately," and $21 \%$ of the participants found it either slightly or not challenging. "Establishment of Student-Centered Approach" had a similar result, with $42.7 \%$ claiming it to be challenging, $32.7 \%$ to be moderate, and $24.7 \%$ claimed it was not challenging. Both challenges were equally found to be the third biggest challenge.

"Students' Behavior Management" and "Course Planning" had an identical mean score of 3.05. They are more likely to be characterized as moderate challenges based on the respondents' feedback, as all percentages are close between "challenging," "moderately," and "not challenging." Table 6 shows that $38.0 \%$ of the teachers rated "Students' Behavior Management" as "moderately," 34.7\% found it either "very challenging" or "challenging," and $24.3 \%$ rated it either "not challenging" or "slightly challenging." "Course Planning" showed a somewhat similar result, with $38.7 \%$ of the participants claiming it to be challenging, $32.0 \%$ rated it as being moderate, and $29.3 \%$ claimed it was not challenging.

Dealing with Individual Differences" and "Communication with Parents" had a similar mean of 2.89 and 2.88 , respectively. Table 7 shows that the highest proportion $42.7 \%$ of the teachers rated "Dealing with Individual Differences" as being moderate and $26 \%$ found it to be "challenging". Based on these percentages, the challenge is identified as a moderate challenge. "Communication with Parents" was claimed to be either not or "slightly challenging" by $38 \%$ of the teachers while $33.3 \%$ claimed the opposite. As this challenge has no significant gap between the contrary opinions, it can be described as a moderate challenge.

Table 8 reveals that "Limited Time of Instruction" is insignificant as a challenge. It is interesting to note that opinions are split: $37.3 \%$ of respondents did not find it challenging, $35.3 \%$ found it as being moderate, and the least proportion $27.3 \%$ found it challenging.

The survey data also revealed the minority of other challenges for new teachers who participated in this research. A noticeable $46.7 \%$ of participants rated "Communication with Administration" and "Setting Examination Paper" as being either "not challenging" or "slightly challenging". A sizable $45.3 \%$ of the participants also found the "Proper Presentation of Cultural Issues Related to English Language Speakers" as not challenging. Half of the teachers $(50.7 \%)$ found "Correcting Examination Paper" as "not challenging" or "slightly challenging", and the majority $(60 \%)$ of the participants did not find "Communication with Colleagues" challenging.

The findings reveal that responses to challenges faced by newcomers to the profession were slightly affected by their level of teaching experience. Holistically, "Dealing with Low English Proficiency Students" posed the greatest challenge. "Establishment of Student-Centered Approach", "Adoption of Various Teaching Methods", "Managing the Negative Attitude of Students toward Learning English" and "Course Planning" were all common in the top five challenges. However, "Limited Time of Instruction" was one of the top five challenges for those with one year of experience (36.67\%), but it posed less of a challenge for those with two and three years' experience $(28.95 \%$ and $23.17 \%$, respectively). "Students' Behavior Management" was one of top five challenges for those with two years of experience and "Communication with Parents" was revealed as one of the top challenges for those with three years' experience.

\section{Research Question 2: What kind of support do new teachers receive in Saudi Arabian schools?}

Respondents were asked to determine to what extent the assistance provided by a supervisor, principal, colleagues, and a trainer helped in decreasing the challenges they face as novice teachers on a scale from "very greatly" to "very poor". 
Table 2. Means and standard deviations of the challenges $(n=150)$

\begin{tabular}{lcc}
\hline & Mean & $\begin{array}{c}\text { Standard } \\
\text { Deviation }\end{array}$ \\
\hline $\begin{array}{l}\text { Dealing with low english } \\
\text { proficiency students }\end{array}$ & 3.75 & 1.17117 \\
$\begin{array}{l}\text { Managing the negative } \\
\text { attitude of students toward } \\
\text { learning english }\end{array}$ & 3.69 & 1.14661 \\
$\begin{array}{l}\text { Adoption of various teaching } \\
\text { methods }\end{array}$ & 3.27 & 1.22555 \\
$\begin{array}{l}\text { Establishment of } \\
\text { student-centered approach }\end{array}$ & 3.27 & 1.23645 \\
$\begin{array}{l}\text { Students' behavior } \\
\text { management }\end{array}$ & 3.05 & 1.29939 \\
$\begin{array}{l}\text { Course planning } \\
\text { Dealing with individual } \\
\text { differences }\end{array}$ & 3.05 & 1.33782 \\
$\begin{array}{l}\text { Communication with parents } \\
\text { Limited time of instruction }\end{array}$ & 2.89 & 1.12648 \\
$\begin{array}{l}\text { The proper presentation of } \\
\text { cultural issues related to } \\
\text { english language speakers }\end{array}$ & 2.88 & 1.36062 \\
$\begin{array}{l}\text { Communication with } \\
\text { administration }\end{array}$ & 2.83 & 1.31459 \\
$\begin{array}{l}\text { Setting examination papers } \\
\text { Correction of examination } \\
\text { papers }\end{array}$ & 2.67 & 1.27793 \\
$\begin{array}{l}\text { Communication with } \\
\text { colleagues }\end{array}$ & 2.59 & 1.22823 \\
\hline
\end{tabular}

Table 9 reveals that new teachers benefit considerably from their colleagues by the mean 3.35. The teachers found a supervisor and principal as the second and third sources of support with mean scores of 2.49 and 2.40, respectively, whereas a trainer was rated as the least effective source of assistance, with a mean score of 1.64.

As shown in Table 10, the top form of assistance for new teachers that mitigated the challenge(s) they encountered was from colleagues. More than half of the participants $(53.3 \%)$ rate their colleagues to be of very great or great assistants in mitigating the challenges that they face as novice teachers. The remaining responses are split: $24.7 \%$ of respondents rated their colleagues' assistance as poor or very poor and $22 \%$ rated them as somewhat helpful. Supervisor assistance was identified as inadequate source of support, with $47.3 \%$ of respondents rating supervisor support as poor or very poor and $32.7 \%$ of participants found supervisors somewhat helpful. The least percentage of participants $(20 \%)$ rated such support as very greatly or greatly helpful in lessening the challenges they face.

The table shows the poor role principals play when it comes to assistance, as more than half of participants (56.7\%) rated principals as a poor to very poor source of assistance for reducing the challenges they encounter. Only $22 \%$ of participants found principals to be very greatly or greatly helpful and $21.3 \%$ of participants found principals somewhat helpful. The
Table 3. Frequency and percentage of "dealing with low english proficiency students"

\begin{tabular}{lccc}
\hline & Frequency & Percent & $\begin{array}{c}\text { Cumulative } \\
\text { percent }\end{array}$ \\
\hline Valid & 7 & 4.7 & 4.7 \\
$\quad$ Not challenging & 15 & 10.0 & 14.7 \\
$\begin{array}{l}\text { Slightly } \\
\text { challenging }\end{array}$ & 39 & 26.0 & 40.7 \\
Moderately & 37 & 24.7 & 65.3 \\
Challenging & 52 & 34.7 & 100.0 \\
Very challenging & & & \\
\hline
\end{tabular}

Table 4. Frequency and percentage of "managing the negative attitude of students toward learning english"

\begin{tabular}{lccc}
\hline & Frequency & Percent & $\begin{array}{c}\text { Cumulative } \\
\text { percent }\end{array}$ \\
\hline Valid & 8 & 5.3 & 5.3 \\
$\quad$ Not challenging & 10 & 6.7 & 12.0 \\
$\begin{array}{l}\text { Slightly } \\
\text { challenging }\end{array}$ & & & \\
Moderately & 50 & 33.3 & 45.3 \\
Challenging & 34 & 22.7 & 68.0 \\
Very challenging & 48 & 32.0 & 100.0 \\
\hline
\end{tabular}

table also reveals the insignificance of a trainer as a source of assistance to overcome the challenges new teachers face. Most participants $(78 \%$ ) found trainers to be a poor or very poor source of assistance in relieving the challenges they face. Only $12.7 \%$ of them found trainers somewhat helpful, whereas only $9.3 \%$ rated trainers' assistance very greatly or greatly.

\section{Research question 3: What types of strategies are effective to implement a teacher induction program as perceived by EFL novice teachers?}

A number of induction practices for novice teachers were investigated based on seven practices identified as being significant in other studies. Respondents were asked to select four practices they believed them to be the most effective in modifying the challenges new teachers face.

Based on the findings presented in Table 11, mentoring and observing veteran teachers were perceived by the majority of participants ( $79 \%$ and $66 \%$, respectively) to be the most important induction strategy that helps mitigate the challenges new teachers face. Attendance at intensive training courses and workshops were also deemed as being important by $56.67 \%$ and $54.00 \%$ of the participants, respectively. A considerable $42.7 \%$ of the participants selected orientation as an effective induction strategy. The supervision of supervisors was perceived as ineffective, as only $15.33 \%$ of the participants deemed it effective. The perception of the ineffectiveness of the supervision of principals as an induction strategy was clear, as only $2.67 \%$ of the participants thought it to be effective induction. 
Table 5. Frequency and Percentage of "adoption of various teaching methods" and "establishment of student-centered approach"

\begin{tabular}{|c|c|c|c|c|}
\hline & \multicolumn{2}{|c|}{$\begin{array}{c}\text { Adoption of various teaching } \\
\text { methods }\end{array}$} & \multicolumn{2}{|c|}{$\begin{array}{c}\text { Establishment of student-centered } \\
\text { approach }\end{array}$} \\
\hline & Frequency & Percent & Frequency & Percent \\
\hline \multicolumn{5}{|l|}{ Valid } \\
\hline Not challenging & 20 & 13.3 & 16 & 10.7 \\
\hline Slightly challenging & 12 & 8.0 & 21 & 14.0 \\
\hline oderately & 50 & 33.3 & 49 & 32.7 \\
\hline Challenging & 43 & 28.7 & 34 & 22.7 \\
\hline Very Challenging & 25 & 16.7 & 30 & 20.0 \\
\hline
\end{tabular}

Table 6. Frequency and percentage of "students' behavior management" and "course planning"

\begin{tabular}{lcccr}
\hline & \multicolumn{2}{c}{ Students' behavior management } & \multicolumn{2}{c}{ Course planning } \\
\cline { 2 - 3 } & Frequency & Percent & Frequency & Percent \\
\hline Valid & 28 & 18.7 & 31 & 20.7 \\
Not challenging & 13 & 8.7 & 13 & 8.7 \\
Slightly & & & & 32.0 \\
Challenging & 57 & 38.0 & 34 & 22.7 \\
Moderately & 27 & 18.0 & 24 & 16.0 \\
Challenging & 25 & 16.7 & 24 & \\
Very challenging & & & & \\
\hline
\end{tabular}

Table 7. Frequency and Percentage of " dealing with individual differences" and "communication with parents"

\begin{tabular}{lcccr}
\hline & \multicolumn{2}{c}{$\begin{array}{c}\text { Dealing with individual } \\
\text { differences }\end{array}$} & Communication with parents \\
\cline { 2 - 3 } & Frequency & Percent & & Frequency \\
\hline Valid & 22 & 14.7 & 34 & Percent \\
Not challenging & 25 & 16.7 & 23 & 15.3 \\
Slightly challenging & 64 & 42.7 & 43 & 28.7 \\
Moderately & 26 & 17.3 & 27 & 18.0 \\
Challenging & 13 & 8.7 & 23 & 15.3 \\
Very challenging & & & 23 & \\
\hline
\end{tabular}

\section{Interview Results}

This section presents a qualitative analysis of the participants' responses to the interview. The participants consisted of five female ESL teachers, employed at different school levels with different degrees of teaching experience. The following format is used to report the assessment of participants' perspectives: (a) first, the interview question is stated; and (b) second, an interpretation of the findings is reported based on the connections, comparisons, and linkages found among the responses.

\section{Interview Question 1: What do you think are the most challenging aspects of being a new teacher? Why is that so?}

All participants mentioned that having students in the class with low English proficiency was the most challenging aspect they had experienced as a new teacher. They reported feeling overwhelmed by the weak or low-level English students and felt that, because of a lack of time, and resources in the educational sector, they were unable to attend to the needs of lower-ability students. One participant reported that an additional challenge was assessing students. As a novice teacher, she claimed, "I was completely ignorant of assessment criteria and strategies, which made it hard for me to demonstrate the students' mastery of any skill or to make decisions that might enhance student achievement."

Another concern, raised by two teachers, was classroom management. The two participants who expressed this concern claimed that disruptive students were having a significant impact on their interactions with the remainder of the class as well as on their teaching efficiency. They stated that problems with classroom management had forced them to forego research-based instructional practices such as project-based learning and cooperative learning in favor of a steady classroom of lectures and textbooks. In her answer 
Table 8. Frequency and percentage of "limited time of instruction"

\begin{tabular}{lccc}
\hline & Frequency & Percent & $\begin{array}{c}\text { Cumulative } \\
\text { percent }\end{array}$ \\
\hline Valid & & & \\
$\quad$ Not challenging & 33 & 22.0 & 22.0 \\
$\begin{array}{l}\text { Slightly } \\
\text { challenging }\end{array}$ & 23 & 15.3 & 37.3 \\
Moderately & 53 & 35.3 & 72.7 \\
Challenging & 19 & 12.7 & 85.3 \\
$\quad$ Very challenging & 22 & 14.7 & 100.0 \\
\hline
\end{tabular}

Table 9. Means and standard deviations of the assistances

\begin{tabular}{lcc}
\hline & Mean & Standard Deviation \\
\hline Colleague & 3.35 & 1.29084 \\
Supervisor & 2.49 & 1.22467 \\
Principal & 2.40 & 1.21512 \\
Trainer & 1.64 & 1.13682 \\
\hline
\end{tabular}

to this question, one teacher stated, "As a novice teacher, I don't have the professional skills to deal with this extreme behavior." All participants reported that they were particularly unprepared for dealing with the challenges they faced, as their pre-service programs did not prepare them for the realities of classrooms, including dealing with low English proficiency students and unruly students.

\section{Interview Question 2: Did you feel like you had the necessary support during your first year of teaching? What support did you have that you found beneficial?}

The responses to this question were affected by whether the participant's workplace was a public or private school. Two of the five interviewees worked in public schools, and they both complained about the total absence of formal support. They claimed that their frequent need to rely on trial-and-error as a means of dealing with challenges hindered them from moving forward to new levels of achievement and had a negative impact on students' achievement as well. They stated that they regularly looked to their colleagues for guidance and advice when facing difficulties, although their colleagues had different areas of specialization. While stating that they had the same few opportunities as veteran teachers to attend training courses, these participants claimed that such courses were ineffective, as they were merely theoretical and did not meet their needs as new teachers.

The remaining three participants, who worked in private schools, reported having some degree of formal support. All three reported that they took part in a formal training course at the start of their employment with these schools. They believed the training courses presented by their schools were beneficial to them, as they exposed them to the latest developments and trends in education and offered practical classroom applications that they could incorporate into their classrooms. It is also interesting to notice that one of the three private-school participants was assigned a mentor at her school, who assisted her through her first month of teaching, provided support with any challenge she faced, and exposed her to new ideas and strategies. Nevertheless, the three participants also agreed that the support provided by their schools was of only limited value in improving their teaching method and equipping them to activate various strategies and that it did not assist them in dealing with challenges such as disruptive or low-ability students, time management, or students' negative attitudes toward learning English.

All five participants stated that they received no support from their schools' principals, as the principals were busy with their administrative duties. Another reason they identified for their principals' ineffectiveness as a source of support was that the principals' role in judging the participants prevented them from seeking help from the principals.

\section{Interview Question 3: Have you considered leaving the profession since your transition from pre-service to in- service?}

Four out of the five interview subjects stated that they have considered leaving the profession. These participants reported that feeling overwhelmed and unsupported had promoted negative attitudes within them towards teaching and students' learning. They felt that they had struggled from their first day in the profession with not having enough time to obtain and organize resources, secure student materials, familiarize themselves with the curriculum and the overall environment, and adequately prepare themselves for the first week of school. They said that they had been expected to perform just like experienced teachers, and they soon realized that they were in a "sink or swim" setting.

The final participant stated that the reason she would stay in teaching was that she "liked teaching." She felt that she had not considered leaving the profession because she found her relatives, colleagues, and fellow graduates from her pre-service program to be a great source of support. She claimed that this support, combined with her growing experience, had enabled her to see progress in both her teaching practice and her confidence level.

\section{DISCUSSION}

This study reveals that novice teachers are confronted with many challenges that hinder them tremendously in their growth as new teachers. The most noticeable challenges reported by the study participants are dealing with low English proficiency students and managing the negative attitudes of students toward learning English. These findings support the results of Al-Seghayer (2014), who reported that the most common constraints were the negative beliefs and attitudes students bring to EFL. This same report also identified additional perceptible challenges: adoption of various teaching methods and the establishment of a student-centered approach, student behavior management, course planning, dealing with individual differences, and communication with parents.

The changeable reality that novice teachers face, as reported in the present study, confirms the results of studies 
Table 10. Frequency and percentage of the assistance

\begin{tabular}{|c|c|c|c|c|c|c|c|c|}
\hline & \multicolumn{2}{|c|}{ Principle } & \multicolumn{2}{|c|}{ Trainer } & \multicolumn{2}{|c|}{ Colleagues } & \multicolumn{2}{|c|}{ Supervisor } \\
\hline & $\mathbf{F}$ & $\%$ & $\mathbf{F}$ & $\%$ & $\mathbf{F}$ & $\%$ & $\mathbf{F}$ & $\%$ \\
\hline Very Poor & 45 & 30.0 & 107 & 71.3 & 20 & 13.3 & 45 & 30.0 \\
\hline Poor & 40 & 26.7 & 10 & 6.7 & 17 & 11.3 & 26 & 17.3 \\
\hline Somewhat & 32 & 21.3 & 19 & 12.7 & 33 & 22.0 & 49 & 32.7 \\
\hline Greatly & 26 & 17.3 & 8 & 5.3 & 50 & 33.3 & 21 & 14.0 \\
\hline Very greatly & 7 & 4.7 & 6 & 4 & 30 & 20 & 9 & 6 \\
\hline
\end{tabular}

discussed in the review of the literature, including those Meister and Melnick (2003), Farrell (2003) and Alromaih (1995). The answers obtained from the novice teachers who participated in this study suggest that these teachers have left their pre-service training with a very limited knowledge of skills for dealing with the reality of teaching. This conclusion reinforces the findings of Alfahadi (2014), who argued that EFL teachers in Saudi Arabia lack sufficient training to deal with various new teaching techniques and activities. The current study found that the participants who work in public schools often deal with challenges by trial-and-error, which reduces their efficiency. Such participants do not go through any induction process and do not receive adequate support from either their school administration, including their principal, supervisor, and trainers, nor any other institutes. However, they did find informal forms of support, such as teacher colleagues and friends, to be somewhat helpful. Conversely, the participants who work in private schools reported having more formal types of support.

This study reveals that mentoring and observing veteran teachers were identified by novice teachers as the two most beneficial strategies for implementing a teacher induction program that could mitigate the challenges they face in their first few years, followed by other strategies, such as attendance at intensive practical training courses, workshops, and orientation. The answers obtained from the novice teachers also suggests that there are relationships between teachers' decisions to leave the profession and the feelings of being overwhelmed by the plethora of responsibilities they have from their first day as teachers.

The answers obtained from the interviews with novices suggest that there is a high potential for teacher attrition in Saudi Arabia. From the perspective of these teachers it appears that the most likely incentives for them to leave the profession are "too much work" along with "lack of support".

\section{CONCLUSION}

\section{Implications of the Study}

The following recommendations are based on the most important findings from this study:

1. The challenges novice teachers face indicate that beginning teachers should go through an induction program. Therefore, it is recommended that the Ministry of Education design and implement an induction model to support the needs of beginning teachers in Saudi Arabia.
2. It is also recommended that the Ministry of Education strengthen teacher preparation programs based on the research findings in this study.

3. When designing and implementing a teacher induction model for new teachers in Saudi Arabia, it is recommended to reduce the teaching schedule for new teachers; this will provide time for them to adjust to their new environments and thus gain the most from the induction program.

4. Mentoring, observing veteran teachers, practical training courses, workshops, and orientation are some induction strategies that are likely to be beneficial for new teachers.

\section{Recommendations for Future Research}

This study examined the challenges that Saudi Arabian EFL novice teachers face, and determined whether these novice teachers have adequate support or would benefit from a formal induction process. The findings indicated that the challenges surrounding novice teachers hinder them in their development as new teachers. The most noticeable challenges reported by the study participants were dealing with low English proficiency students and managing the negative attitudes of students toward learning English. This report also revealed additional perceptible challenges: adoption of various teaching methods and the establishment of a student-centered approach, student behavior management, course planning, dealing with individual differences, and communication with parents. Based on the findings of this study, efforts should be made by stake holders in education to provide adequate support to novice teachers. Mentoring and observing veteran teachers were identified by novice teachers as the two most beneficial strategies for implementing a teacher induction program that could mitigate the challenges they face in their first few years.

Furthermore, this study provides a foundation for further researches that could provide deeper understandings of the experience of EFL novice teachers and the types of support and training they require in Saudi Arabia. The following recommendations may have extended the scope of results:

1. A replication of this study with an equal sample size of both genders is recommended to determine if male novice teachers' perceptions regarding the needs of beginning teachers and the value of induction programs are similar to or different from those of females.

2. It is recommended that this study be replicated in studies taking place at specific school levels, including the 
Table 11. Frequency and percentage of the induction strategies as perceived by participants

\begin{tabular}{lcc}
\hline & Frequency & Percent \\
\hline Mentoring & 114 & 76.00 \\
$\begin{array}{l}\text { Observing veteran } \\
\text { teachers }\end{array}$ & 99 & 66.00 \\
Training courses & 85 & 56.67 \\
Workshops & 81 & 54.00 \\
Orientation & 73 & 48.67 \\
$\begin{array}{l}\text { The supervision of } \\
\text { supervisors }\end{array}$ & 23 & 15.33 \\
$\begin{array}{l}\text { The supervision of } \\
\text { principals }\end{array}$ & 4 & 2.67 \\
\hline
\end{tabular}

elementary, intermediate, and high school levels, to explore whether the needs and challenges of new teachers at a specific level differ from those of other levels.

3. A future study could seek to gain a larger number of participants from rural areas of the country in order to determine if teaching in rural versus urban areas contributes to perceptions of challenges during the beginning years of teaching.

4. An additional recommendation for further research involves using in-depth interviews with regional education directors, administrators, and veteran teachers, in order to gather more detailed information about the needs of beginning teachers and more effective ways of helping them to successfully adjust during their first year of teaching.

\section{REFERENCES}

Alfahadi, A. (2014). Saudi teachers'views on appropriate cultural models for EFL textbooks: Insights into TESOL teachers' management of global cultural flows and local realities in their teaching worlds (Unpublished doctoral dissertation). University of Exeter, Exeter, UK.

Alharbi, A. (2011). The development and implementation of a CPD programme for newly qualified teachers in Saudi Arabia (Unpublished doctoral dissertation). University of Southampton, UK.

AL-Hazmi, S. U. L. T. A. N. (2003). EFL teacher preparation programs in Saudi Arabia: Trends and challenges. TESOL Quarterly, 37(2), 341-344.

Alkubaidi, M. A. (2014). The Relationship between Saudi English Major University Students' Writing Performance and Their Learning Style and Strategy Use. English Language Teaching, 7(4), 83-95.

ALRomaih, S. (1995). Professional and personal growth needs of beginning high school teachers in Saudi Arabia and the need for induction programs as viewed by administrators (University of Southampton). George Washington University, USA.

Al-Seghayer, K. S. (2014). The actuality, inefficiency, and needs of EFL teacher-preparation programs in Saudi Arabia. International Journal of Applied Linguistics and English Literature, 3(1), 143-151.
Ball, D., \& Cohen, D. (1999). Toward a practice-based theory of professional education. Teaching as the Learning Profession San Francisco: Jossey-Bass.

Barnett, B., Hopkins-Thompson, P., \& Hoke, M. (2002). Assessing and supporting new teachers. Lessons from the southeast. Chapel Hill, NC: The Southeast Center for Teaching Quality.

Beck, C., \& Kosnick, C. (2000). Associate teachers in pre-service education: clarifying and enhancing their role. Journal of Education for Teaching, 26(3), 207-224.

Bickmore, D. L., \& Bickmore, S. T. (2010). A multifaceted approach to teacher induction. Teaching and teacher education, 26(4), 1006-1014.

Brighton, C. M. (1999). Keeping good teachers: Lessons from novices. A better beginning: Supporting and mentoring new teachers, 197-201.

Brogden, L. M., Page, B., \& Farrell, T. S. C. (2008). Novice language teachers: Insights and perspectives for the first year. London, England: Equinox.

Bryman, A. (2008). Social research methods (3 ${ }^{\text {rd }}$ ed.). Oxford: Oxford University Press

Caspersen, J., \& Raaen, F. D. (2014). Novice teachers and how they cope. Teachers and Teaching, 20(2), 189-211.

Clarke, A., \& Jarvis-Selinger, S. (2005). What the teaching perspectives of cooperating teachers tell us about their advisory practices. Teaching and Teacher Education, $21,65-78$

Cronbach, L. J. (1951). Coefficient alpha and the internal structure of tests. Psychometrika, 16(3), 297-334.

Darling-Hammond, L. (2003). Keeping good teachers: Why it matters, what leaders can do? Educational Leadership, 60(8), 6-13.

Deal, T. E., \& Chatman, R. M. (1989). Learning the ropes alone: Socializing new teachers. Action in Teacher Education, 11, 21-29.

Fareh, S. (2010). Challenges of teaching English in the Arab world: Why can't EFL programs deliver as expected?. Procedia-Social and Behavioral Sciences, 2(2), 3600-3604.

Farrell, T. S. (2003). Learning to teach English language during the first year: Personal influences and challenges. Teaching and Teacher Education, 19(1), 95-111.

Fantilli, R. D., \& McDougall, D. E. (2009). A study of novice teachers: Challenges and supports in the first years. Teaching and teacher education, 25(6), 814-825.

Feiman-Nemser, S. 1983. Learning to teach. In L.Shulman and G. Sykes (Eds.). Handbook of teaching and policy (pp. 150-71). New York: Longman.

Feiman Nemser, S., Parker, M. B., \& Zeichner, K. (1993). Are mentor teachers teacher educators? In D. McIntyre, H. Hagger, \& M. Wilkin (Eds.), Mentoring: Perspectives on school-based teacher education (pp. 147-165). London: Kogan Page.

Gay, L.R. (1987). Educational Research: Competencies for analysis \& application ( $3^{\text {rd }}$ edition). Columbus, $\mathrm{OH}$ : Merrill Publishing Company.

Giraldo, F. (2014). The Impact of a Professional Development Program on English Language Teachers' Class- 
room Performance. Profile Issues in Teachers Professional Development, 16(1), 63-76.

Harrison, J. K., Lawson, T., \& Wortley, A. (2005). Mentoring the beginning teacher: Developing professional autonomy through critical reflection on practice. Reflective Practice, 6(3), 419-441.

Hebert, E., \& Worthy, T. (2001). Does the first year of teaching have to be a bad one? A case study of success. Teaching and teacher education, 17(8), 897-911.

Heller, D. A. (2004). Teachers Wanted: Attracting and Retaining Good Teachers. Association for Supervision and Curriculum Development (ASCD), 1703 North Beauregard Street, Alexandria, VA 22311.

Huberman, M. (1989). The professional life cycle of teachers. Teachers College Record, 91(1), 31-57.

Ingersoll, R. M., \& Smith, T. M. (2004). Do teacher induction and mentoring matter?. NASSP bulletin, 88(638), $28-40$.

Ingersoll, R. M., \& Strong, M. (2011). The Impact of Induction and Mentoring Programs for Beginning Teachers A Critical Review of the Research. Review of Educational Research, 81(2), 201-233.

Lave, J., \& Wenger, E. (1998). Communities of practice. Retrieved June, 9, 2008.

Meister, D. G. \& Melnick, S. (2003). National New Teacher Study: Beginning Teachers' Concerns. Action in Teacher Education, 24(A), 97-94.

Shafie, L. A., \& Nayan, S. (2010). The Roles of University English Teachers in Malaysia, Journal of Language Teaching and Research, 1(3), 262-265
Smith, T. M., \& Ingersoll, R. M. (2004). What are the effects of induction and mentoring on beginning teacher turnover? American Educational Research Journal, 41(3), 681-714.

Solmon, M. A., Worthy, T., \& Carter, J. A. (1993). The interaction of school context and role identity of firstyear teachers. Journal of Teaching in Physical Education, 12(3), 313-328.

Streiner, D. L. (2003). Starting at the beginning: an introduction to coefficient alpha and internal consistency. Journal of personality assessment, 80(1), 99-103.

Sundli, L. (2007). Mentoring - A new mantra for education?. Teaching and teacher education, 23(2), 201-214.

Tashakkori, A., \& Teddlie, C. (1998). Mixed methodology: Combining qualitative and quantitative approaches. Applied Social Research Methods Series (Vol. 46). Thousand Oaks, CA: Sage.

Veenman, S. (1987). On becoming a teacher: An analysis of initial training. Paper presented at the Conference on education of the World Basque Congress. (ERIC Document Reproduction Service No. Ed 312 231).

Veenman, S. (1984). Perceived problems of beginning teachers. Review of Educational Research, 54(2), 143-178.

Villar, A. 2004. Measuring the benefits and costs of mentor-based induction: A value-added assessment of new teacher effectiveness linked to student achievement. Santa Cruz, CA: New Teacher Center.

Whisnant, E., Elliott, K., \& Pynchon, S. (2005). A review of literature on beginning teacher induction. Center for Strengthening the Teaching Profession. 


\section{Appendix A: Instrument}

Section 1: Personal Information

1. What is your gender?

- Female

- Male

2. How long have you been teaching?

- Less than one year

- One year

- Two years

- Three years

3. What was your highest degree when you start teaching?

- Diploma

- Bachelor degree

- Master degree

- $\mathrm{PhD}$

Section 2: The major challenges Saudi Arabian EFL novice teachers face in their first years

1. To what extent have you found the following to be challenging as a novice teacher?

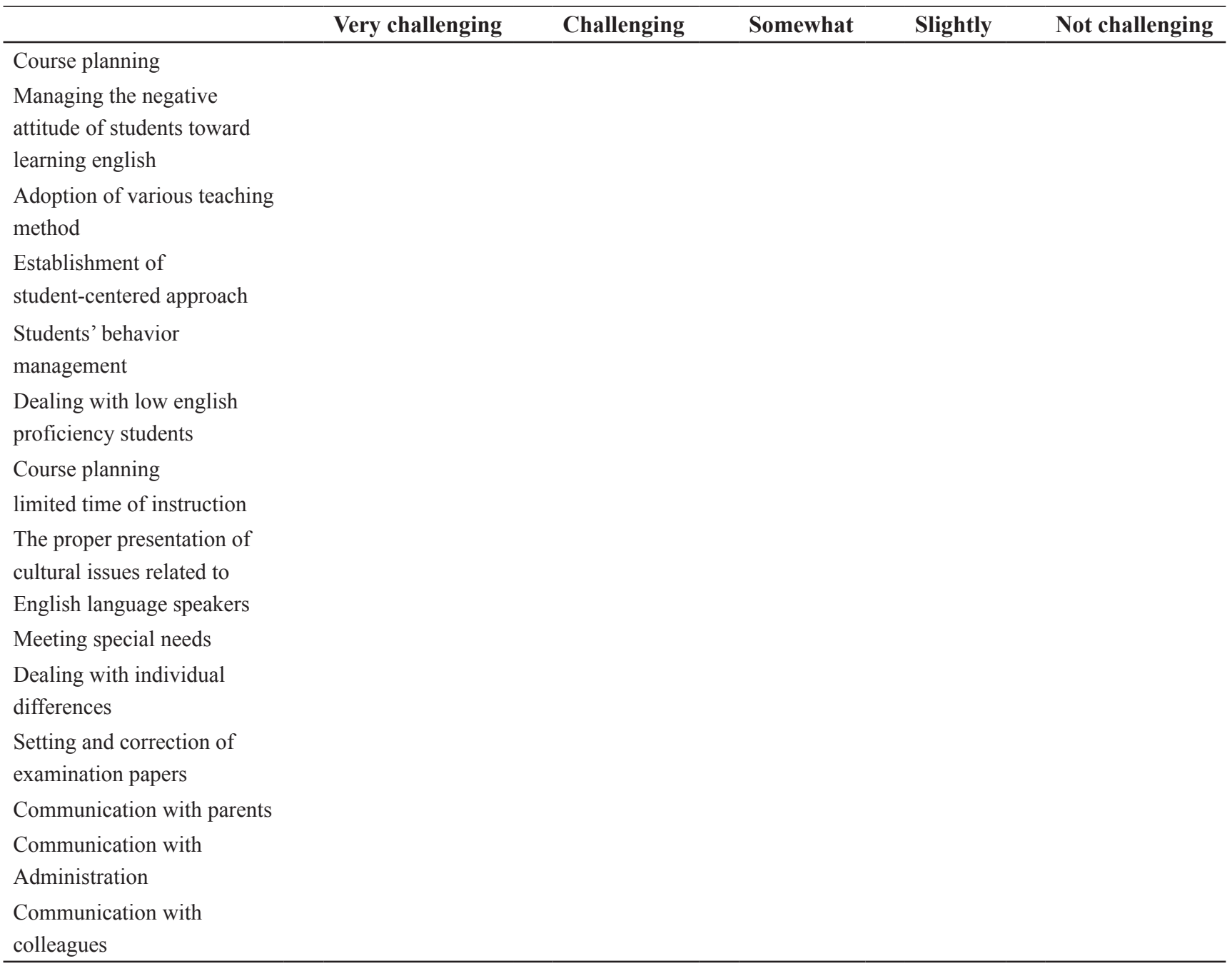


Section 3. Types of assistance new teachers can currently find in saudi arabian schools

2. To what extent has the following assisted you in mitigating the challenges you face as a novice teacher

\begin{tabular}{|c|c|c|c|c|c|}
\hline & Very Greatly & Greatly & Somewhat & Poor & Very Poor \\
\hline \multicolumn{6}{|c|}{ Supervisor } \\
\hline \multicolumn{6}{|l|}{ Principal } \\
\hline \multicolumn{6}{|l|}{ Colleague } \\
\hline $\begin{array}{l}\text { Mentor, } \\
\text { coach }\end{array}$ & & & & & \\
\hline
\end{tabular}

Section 4: Needs for Induction Program

3. What are the induction practices that would help mitigate the challenges new teachers face, as perceived by new teachers? (select four practices)

- Mentoring

- observing veteran teachers

- training courses

- workshops

- orientation

- The supervision of supervisors

\section{Appendix B: Interview Questions}

1. What do you think are the most challenging aspects of being a new teacher? Why is that so?

2. Did you feel like you had the necessary support during your first year of teaching? What support did you have that you found beneficial?

3. Have you considered leaving the profession since your transition from pre-service to in-service? 